\title{
WATER SUPPLY MODULE AS DEFINITIVE INDICATOR IN JUSTIFYING OF PARAMETERS OF COMPLEX IRRIGATION SYSTEMS
}

\author{
Anatoly Rokochynskiy ${ }^{1}$, Yury Mazhayskiy ${ }^{2}$, Pavlo Volk ${ }^{1}$, Vasyl Turcheniuk ${ }^{1}$, \\ Ludmila Tokar $^{1}$, Liubov Volk ${ }^{1}$, Olga Chernikova ${ }^{3}$ \\ ${ }^{1}$ National University of Water and Environmental Engineering, Russia; ${ }^{2}$ All-Russian Research \\ Institute of Hydrotechnics and Melioration named after A.N. Kostyakova, Russia; ${ }^{3}$ Academy of Law \\ Management of the Federal Penal Service of Russia, Russia \\ a.m.rokochinskiy@nuwm.edu.ua, director@mntc.pro,p.p.volk@nuwm.edu.ua, \\ v.o.turchenuk@nuwm.edu.ua, 1.o.tokar@nuwm.edu.ua,1.r.volk@ukr.net, chernikova_olga@inbox.ru
}

\begin{abstract}
One of the most important design parameters of dehumidification and irrigation systems (CIS) operating in both dehumidification and irrigation mode is the distance between the drains of the regulating collector and drainage network. Therefore, to justify the determining indicators and parameters of the drainage network, when it operates in the subsurface irrigation mode, similar to the previously studied drainage mode, approaches, methods and dependencies for their calculation are generalized and analyzed, a set of multiple factors of influence is justified (head over drains, soil filtration coefficient, time of ground water level rise, depth of drainage, distance from the drainage axis to the water barrier, etc.), which are elements of a complex multiparametric model. By applying the methods of statistical modeling and probability theory, mathematical models were developed to determine the mean square deviation of the determining factor from the established set of indicators of the function under study. Based on the obtained analytical and graphical results, it was found that, as with drainage in the dehumidification mode, with subsurface moisture, the drainage parameters are significantly affected (at the level of $73 \% \ldots 94 \%$ ) by the head above the drains $58 \ldots 82 \%$, the soil filtration coefficient and the time of raising the ground water level is $12 \ldots 18 \%$. These same indicators directly or indirectly form the water supply module during irrigation measures, the value of which quantitatively and qualitatively reflects the efficiency of humidification of the drained soils according to their profile and the entire drained array within the system and determines the parameters of the collector and drainage network operating in the subsurface irrigation mode.
\end{abstract}

Keywords: water supply module, defining indicator, justification of parameters, complex irrigation systems, subsurface irrigation.

\section{Introduction}

Complex irrigation systems (CIS), in contrast to drainage systems, create a more favorable water regime and conditions for growing crops.

The subsurface irrigation is the traditional and most widespread method of water regulation on drained lands during dry growing seasons. For subsurface irrigation, as well as for dehumidification, the same collector-drainage network is used. It determines the technical, economic and environmental efficiency of the CIS as a whole. Moistening of the root layer of soil is carried out by regulating the groundwater level (GWL) by means of moistening sluicing.

The main part of the existing CIS, built mainly in the 70-80s of the last century, has exhausted its resource and does not provide the design parameters of water regulation. In addition, the ongoing climate changes necessitate the transfer of their operating mode from periodic to regular irrigation, the associated improvement of water regulation technology, type, design and parameters of the system and its main technical elements, respectively, their reconstruction and modernization to increase the overall technological, economic and environmental effectiveness of their functioning $[1 ; 2]$.

One of the most important design parameters of double-acting systems operating in both dehumidification and irrigation modes is the distance between the drains of the regulating collectordrainage network.

The multi-parameter and multifunctionality of the drainage, which operates in the mode of subsurface irrigation, are determined by a number of factors influencing it, and reflect the objective complexity of their determination. This led to the development of a large number of methods and models to substantiate them.

In this regard, it is of interest to analyze and generalize the approaches, methods and dependencies for determining the inter-drainage distances of the CIS, with subsurface irrigation, and to find out the significance of the influence of the main parameters that directly or indirectly affect the distance between drains, similar to the previously studied drainage regime [3; 4]. 
At the same time, a characteristic feature of the CIS with bilateral regulation is that the processes of water flow in the elements of a closed collector-drainage network (CCDN) during its operation in the mode of drainage and subsurface irrigation are similar, but mutually opposite in their implementation.

Accordingly, the connection between the groundwater level regime of the reclaimed field and the CCDN is ensured by the transformation of the movement of a relatively uniform and continuous filtration flow into a heterogeneous structure of a set of isolated water turbulent flows in hierarchically and hydraulically connected pressure drainage pipelines, as constituent elements of the CCDN, and the speeds during its operation in the mode dehumidification, and on the contrary - when it operates in the mode of subsurface irrigation.

This allows us to carry out this research according to a scheme similar to the earlier research of the drainage operation in the drainage mode $[3 ; 4]$.

\section{Materials and methods}

The existing hydromechanical and empirical methods were analyzed and generalized to solve this problem, as well as the main calculated dependencies for determining the parameters of drainage, which operates in the mode of subsurface irrigation. This was done by such scientists as Darcy, Dupuis, I. Boussuneska, S.F. Averyanov, P.Ya. Polubarinov-Kochin, M. Ya. Yangol, N.N. Verigin, A.I. Ivitskiy, S.V. Vasiliev, A.I. Verbitskiy, Sh. I. Brusilovskiy, A. Yu. Dirce, A. Kusta, P. Balzaryavichus, A. Ya. Oleinik, V.L. Polyakov, I. Nikolskiy-Gavrilov and others [5-9]. Among foreign scientists, the most famous developments are the developments of Hooghoudt, Ritzema, Skaggs, Van Schilfgaarde, Mishra and Singh, van Genuchten, Mualem, etc. [10].

To substantiate the defining indicators and parameters of the drainage network during its operation in the mode of subsurface irrigation, similarly to the previously investigated mode of drainage, a set of multiple influencing factors was justified (pressure over drains, soil filtration coefficient, time of groundwater level rise, depth of the drain, distance from the axis of the drain to the aquiclude, etc.), which are elements of a complex multi-parameter model.

By applying the methods of statistical modeling and probability theory, mathematical models were developed to determine the standard deviation of the determining factor from the established set of indicators of the researched function.

With the help of the obtained analytical and graphic results, from the selected set, the factors that mostly affect the parameters of the collector-drainage network during its operation in the mode of subsurface irrigation were established.

On the basis of the developed mathematical models for determining the standard deviation of the determining factor from the established set of determining indicators of the investigated function, the confidence intervals of the interdrain distances of the collector-drainage network of the CIS operating in the mode of subsurface irrigation were determined.

\section{Results and discussion}

At different stages of the development of land reclamation science, two main methods for calculating the parameters of agricultural drainage operating both in the drainage mode and in the subsoil moistening mode were determined - empirical, based mainly on the statistical processing of data from numerous field studies, and hydromechanical, based on the theoretical foundations of water movement in natural and technical systems.

The empirical method is mainly based on the calculation of the water balance of the reclaimed soil and presents a quantitative characteristic of its water regime: in case of subsurface irrigation, this is the water supply module as the intensity of the supply of moistening water to the soil profile or to the drained massif as a whole. According to this method, the distance between drains, as in the case of drainage, is calculated according to factors influencing the intensity of drainage operation in the mode of subsurface moistening (granulometric composition, water-physical and physicochemical properties of the soil, evaporation rate, water permeability of rocks, etc.).

This method is based on the assumption that the heavier the soil, the more its filtration properties decrease, and the less the distance between drains, which operate with subsurface irrigation. 
A significant advantage of the empirical method for calculating the distance between drains operating in the subsurface irrigation mode is its ease of use. This method also has disadvantages. It is based mainly on the use of long-term field observation data on changes in groundwater levels during subsurface irrigation and requires additional costs for its implementation. In addition, it has a number of applications that are determined by the multiple zonal conditions of the object under study. Therefore, it can give only an approximate result and needs further theoretical substantiation.

The hydromechanical method for determining the distances between drains during subsurface irrigation is the most theoretically justified, but it does not take into account the economic, environmental, and also some mode-technological aspects of the drainage operation. Most of the formulas obtained on the basis of this method do not take into account the water supply conditions in the phase of the rise in the groundwater level, which is more intense than the phase of decline. If this condition is not taken into account, the error in determining the distance between drains can be from 3 to $40 \%$, depending on the duration of the One of the most important design parameters of double-acting systems operating in both dehumidification and irrigation modes is the distance between the drains of the regulating collector-drainage network. period. However, as the most theoretically substantiated, this method allows for a qualitative analysis of the factors of hydrodynamic processes occurring in soil with subsurface moisture.

In Ukraine, one of the most well-known and used dependencies for calculating the distances between drains in the early stages of construction of the CIS is the formula of A.M. Yangolya [5; 8]

$$
B=2 \alpha \sqrt{\frac{t_{p} k\left(h_{0}^{2}-h_{1} \cdot h_{2}\right)}{\delta\left(0,5 h_{0}+\mu-h_{1}\right)}},
$$

where $B$-distance between drains, $\mathrm{m}$;

$\alpha$ - coefficient depending on the depth of the aquiclude;

$t_{p}$ - duration;

$k$ - coefficient of filtration of the permeable layer of soil, $\mathrm{m} \cdot \mathrm{day}^{-1}$;

$h_{0}$ - retaining level above the drain, $\mathrm{m}$;

$h_{1}, h_{2}$ - groundwater levels, counting from the bottom in the middle between the drains respectively before and after backwater, $\mathrm{m}$;

$\delta$-active soil porosity, fraction of a unit; $\mu$-parameter determined by dependence

$$
\mu=\frac{h_{2}^{2}}{2 \sqrt{h_{0}^{2}-h_{2}^{2}}} \cdot \operatorname{arcs} h \sqrt{\frac{h_{0}^{2}}{h_{2}^{2}}-1} .
$$

One of the most important design parameters of double-acting systems operating in both dehumidification and irrigation modes is the distance between the drains of the regulating collectordrainage network. In particular, for homogeneous soil with atmospheric and ground water supply for the case when the distance from the axis of the drain to the aquiclude $T_{D} \leq B / 4$, the distance between the drains during the moistening work of drainage is determined by the formula

$$
B=4\left(\sqrt{\Phi^{2}+\frac{H T}{2 q}}-\Phi\right),
$$

where $\Phi$ - total filtration resistances.

$$
\Phi=\frac{T_{D}}{\pi} \ln \left(\frac{2 T_{D}}{\pi D}\right)+\frac{2 h_{0}}{\pi} \ln \frac{4 h_{0}}{\pi D}+\frac{T_{D} \Phi_{0}}{\pi}+\frac{2 h_{0} \Phi_{0}}{\pi},
$$

where $D$ - outer diameter of the drain, $\mathrm{m}$;

$\Phi_{0}$ - filtration resistance by the nature of the opening of the aquifer;

$H$ - design head, m;

$T$ - formation conductivity, $\mathrm{m}^{2} \cdot$ day $^{-1}$;

$q$ - intensity of water supply, $\mathrm{m} \cdot$ day $^{-1}$;

$T_{D}$-distance from the axis of the drain to the aquiclude, $\mathrm{m}$. 
The scheme for calculating the distances between the drains of the CIS operating in the mode of subsurface irrigation for the calculated dependence (3) is shown in Fig 1.

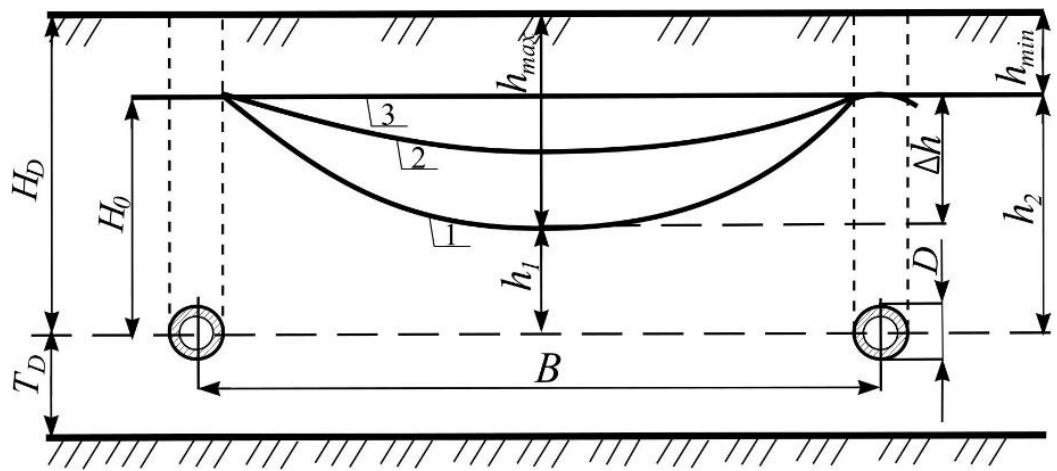

Fig. 1. Scheme for calculating the distance between drains of complex irrigation systems operating in the mode of subsurface irrigation: $1 ; 2 ; 3$ - groundwater levels; $T_{D}$-distance from the axis of the drain to the aquiclude; $H_{D}$ - depth from the ground surface to the axis of the drain; $H_{0}$ - water pressure in the drain; $h_{1}$ - distance from the axis of the drain to the GWL before moistening in the middle between the drains; $h_{2}$ - distance from the axis of the drain to the GWL after moistening in the middle between the drains

The formula of V.L. Polyakov [11,12] is very promising for substantiating the distance between humidifier drains $L_{W}$ in the design of CIS. The formula was obtained by him as a result of subsequent research

$$
L_{w}=\sqrt{\frac{3 k_{e} m_{c} t_{w}}{\mu_{w}\left(S_{w}\right) \ln \frac{\Delta m_{w}}{m_{w}-M+S_{w}}}+9 \Phi_{w}^{2}}-3 \Phi_{w},
$$

where $k_{e}$-weighted average filtration coefficient;

$m_{c}$ - average power of the filtration flow;

$t_{w}$ - preset time and rate $S_{w}$ (optimal depth of groundwater level by the end of the moistening event) of irrigation;

$\mu_{w}$ - average value of the coefficient of the averaged lack of saturation;

$\Delta m_{w}=m_{w}-m_{0}$

$m_{0}-$ initial pressure in drains;

$m_{w}-$ pressure in drains;

$M$ - full thickness of the soil-ground layer (from the aquiclude to the surface of the earth).

Thus, analyzing the main methods and models for determining the inter-drainage distances during subsurface irrigation, it can be seen that as a result of the extreme complexity of the heterogeneous processes that occur in wetted areas, scientists have developed many dependencies, which to one degree or another take into account many factors that determine the design conditions and affect the calculation of drainage parameters.

Consequently, the complexity and multivariance of the models for calculating the inter-drainage distances for subsurface irrigation determine the objective need to study the significance of the influence of the different nature of the factors of the moistening action of drainage, both individually and in interaction with others. This approach allows the study to be carried out within a wide range of changes in the initial parameters.

Fig. 2 shows a structural and logical diagram that reflects the influence of the main conditions of drainage (climatic, soil, relief, etc.) when moistening drained lands and multiple factors of influence (water supply module, head above the drain, time of moistening, distances from the axis of the drain to the aquiclude, drain diameter and drain filter characteristic) on its parameters and are elements of a complex multi-parameter model.

It should be noted that in many dependencies for calculating the interdrain distances during the moistening work of drainage, the theory of hydrodynamic filtration does not exhaustively describe the laws of water movement, since many factors affect the structure and length of the filtration flow in this 
case. But at the same time, the direct influence on the groundwater level of such factors as the soil filtration coefficient, the pressure above the drain and the time of moistening is clearly established.

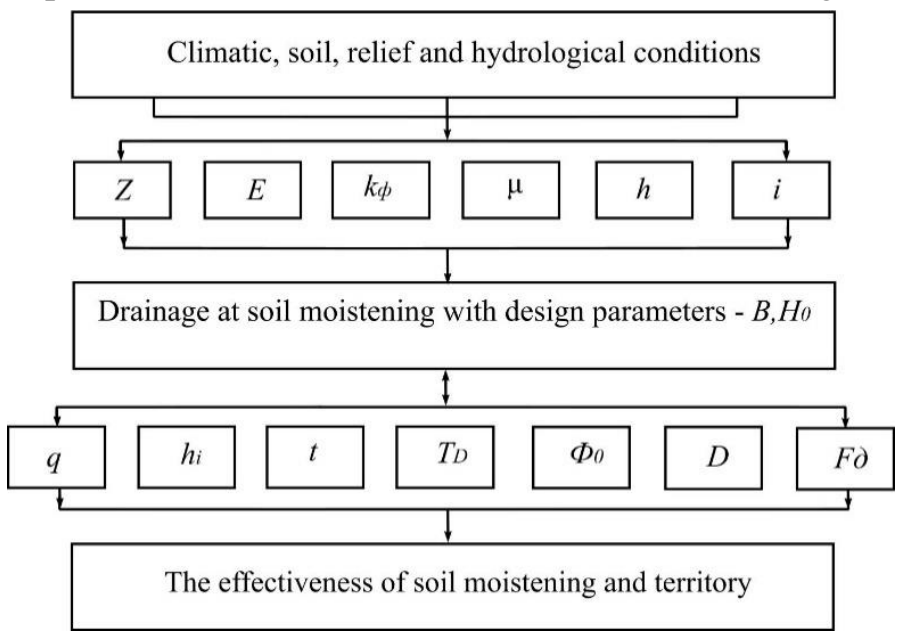

Fig. 2. Structural and logical diagram of formation of work or the action of drainage, which operates in the mode of subsurface irrigation: $k_{\phi}$ - filtration coefficient; $z$-sediment layer; $E$ - evaporation layer; $\mu$-coefficient of water supply; $h_{i}$ - depth of the GWL; $i$-slope of the ground surface; $\Phi_{0}$ - filtration resistance by the nature of the opening of the aquifer; $q$ - water supply module;

$H_{0}$ - water pressure in the drain; $t$ - irrigation time; $T_{D}$ - distance from the axis of the drain to the aquiclude; $D$-drain diameter; $F_{\partial}$ - drainage filter characteristic

In addition, at present, models for determining inter-drainage distances, both during drainage and subsurface irrigation, are considered only in relation to the soil, and not the territory of the drained massif as a whole, and do not take into account the variation in the determining factors of the drainage action along the profile and area of the CIS.

Thus, the efficiency of drainage in the mode of subsurface irrigation directly depends on its design parameters, primarily on the distance between drains. In this case, the spacing between drains, with subsurface irrigation, depends on many factors that are interconnected and can be independent in terms of probabilistic content.

Consequently, the spacing between drains during subsurface irrigation, according to the analysis of its calculated dependences, is a complex multiparametric function (Fig. 2), in which it is advisable to identify the parameters that have the greatest influence on the final result of its formation.

Therefore, it is of interest to study the influence of the variability of the main factors on the distance between drains under subsurface moisture. To solve the formulated problem, the methods of statistical modeling and probability theory were applied, the essence of which is as follows.

As in the case of dehumidification [3], at present the design of CIS facilities is based on deterministic dependencies. In this case, the defining parameter $Y$ characterizing the performance of the system is often a function of several arguments $x_{i}$, that is, we have a function of the form [13-16].

$$
Y=F\left(x_{1}, x_{2}, \ldots, x_{n}\right) .
$$

If the deterministic dependencies are built on the basis of a sufficient amount of experimental data, then the value of the function for the corresponding values of the arguments will be equal to the mathematical expectation

$$
m_{Y}=F\left(m_{x_{1}}, m_{x_{2}}, \ldots, m_{x_{n}}\right) .
$$

Such analytical deterministic relations can be used to estimate the mean square deviations of a function.

In the overwhelming majority of cases, function (6) is nonlinear. However, in a narrow range of variation of their arguments, nonlinear functions can be approximately replaced by linear ones. For this, the function linearization method is used [15]. 
If the values $x_{1}, x_{2}, \ldots x_{n}$ are not correlated, then the variance and standard deviation of the function are equal:

$$
\begin{gathered}
D_{Y}=\sum_{i=1}^{n}\left(\frac{\partial F}{\partial x_{i}}\right)_{m}^{2} D_{x_{i}}, \\
\sigma_{Y}^{2}=\sum_{i=1}^{n}\left(\frac{\partial F}{\partial x_{i}}\right)_{m}^{2} \sigma_{x_{i}}^{2} .
\end{gathered}
$$

Partial derivatives in dependencies (8), (9) with an $m$ index mean that their value is calculated at $x_{i}=m_{i}$. Expressions for the determination of partial derivatives are obtained by differentiating the analytical deterministic dependence for function (7).

To assess the reliability of the values of the function, one must have not only its numerical characteristics (mathematical expectation, variance, standard deviation), but also the distribution law of the function.

In many cases, the values of the arguments are influenced by a significant number of factors, as a result of which the distribution of the arguments is close to normal. Therefore, the function also has a normal distribution with parameters that are determined by the formulas (7) - (9) [14-16].

In this case, on the basis of existing theoretical studies the following dependence was used to determine the boundaries of the confidence interval of the $Y$ function

$$
I_{Y, \beta}=\left(m_{Y}-t_{\beta} \sigma_{Y} ; m_{Y}+t_{\beta} \sigma_{Y}\right),
$$

where $m_{Y}-$ mathematical expectation of the function $Y$ in the vicinity of non-critical points;

$t_{\beta}-$ number of standard deviations $\sigma_{Y}$ that need to be postponed from its mean $\bar{y}=m_{Y}$;

$\beta$ - probability of confidence with which the random variable is covered by the interval (10).

Based on the results of the analysis of dependencies for calculating drainage parameters with subsurface irrigation, it was found that due to the complexity and multifactorial nature of this phenomenon, a significant number of methods and models have been developed for calculating the distances between drains.

Therefore, to reveal the influence of the main factors on the parameters of the values of the distances between drains during subsurface irrigation, we used, according to SBS V.2.4-1-99 [16], a general equation that takes into account the development of O. Ya. Oleinik, A.I. Murashko and V.L. Polyakov. This equation also takes into account the structural features of the design and the features of the work of horizontal material drainage. The effectiveness of its application has been confirmed by other researchers and practitioners both in the drainage zone and in the zone of irrigation reclamation.

To analyze the distance between drains in case of subsurface irrigation, equations $(3,4)$ and a calculation scheme (Fig. 1) were used.

Analyzing the relation between the parameters of formulas (3) and (4), it is seen that

$$
B=f\left(H_{D} ; T_{D} ; k_{\Phi} ; h ; \Phi_{0} ; t ; D\right),
$$

where $t, D$ and $\Delta h$-parameters for each specific case are set as constant values.

The rest of the parameters of function (11), by their nature, relate to random variables, that is, they have their own variation on the area of the system.

Taking into account formula (9) and functional dependence (11), the mean-square value of the distance between drains with subsurface irrigation is.

$$
\sigma_{B}^{2}=\underbrace{\left(\frac{\partial B}{\partial H_{D}} \sigma_{H_{D}}\right)^{2}}_{\Pi_{H_{D}}}+\underbrace{\left(\frac{\partial B}{\partial T_{D}} \sigma_{T_{D}}\right)^{2}}_{\Pi_{T_{D}}}+\underbrace{\left(\frac{\partial B}{\partial H_{k_{\phi}}} \sigma_{k_{\Phi}}\right)^{2}}_{\Pi_{k_{\phi}}}+\underbrace{\left(\frac{\partial B}{\partial h} \sigma_{h}\right)^{2}}_{\Pi_{h}}+\underbrace{\left(\frac{\partial B}{\partial \Phi_{0}} \sigma_{\Phi_{0}}\right)^{2}}_{\Pi_{\Phi_{0}}},
$$

where $\Pi_{i}$ - percentage of the corresponding parameters of dependence (12) in the value $\sigma_{B}{ }^{2}$. 
To implement the assigned task, statistical modeling was planned and carried out using generalized averaged data on the most common soil and conditions of drained territories.

The analysis of the influence of the parameters of the indicators on the distance between the drains during subsurface irrigation was carried out by conducting a machine experiment on the options that consider the following variable conditions:

- by GWL of water $h=0.5 ; 0.6 ; 0.7 ; 0.8 \mathrm{~m}$;

- duration of groundwater level rise $t=2 ; 4 ; 7 ; 10$ day;

- filtration coefficient $k_{\Phi}=0.5 ; 1.0 \mathrm{~m} \cdot$ day $^{-1}$;

- depth of the drain $H_{D}=1 \mathrm{~m}$;

- distance from the axis of the drain to the aquiclude $T_{D}=2 \mathrm{~m}$;

- considered drains from pottery pipes;

- outer diameter $D=0.055 \mathrm{~m}$;

- filtration resistance $\Phi_{0}=1$.

Based on the results of a machine experiment, a histogram of the influence of changing natural and design factors of drainage parameters on the distance between drains during subsurface irrigation was constructed, shown in Fig 3.

Since the geometric and mechanical content of the factors - the depth from the soil surface to the axis of the drain and the depth of the groundwater level - are the pressure forming values, therefore, the percentage of the influence of the pressure in the drain on the distance between the drains during subsurface irrigation is reflected by the parameter

$$
\Pi_{H_{0}}=\Pi_{H_{D}}+\Pi_{h} .
$$

The corresponding parameters $\Pi_{i}$ in Fig. 3 are presented as a percentage from $\sigma_{B}{ }^{2}$. The obtained results of the analysis of the influence of the parameters of the main indicators on the distance between the drains at subsurface irrigation show (Fig. 3) that the specific gravity of the pressure above the drains is $58 \ldots 82 \%$, and the filtration coefficient is $12 \ldots 18 \%$. This indicates that, similar to the drainage flow module studied in works $[3 ; 4]$, mainly the pressure above the drains, the soil filtration coefficient and the time of groundwater rise, directly or indirectly form the water supply module with subsurface irrigation.

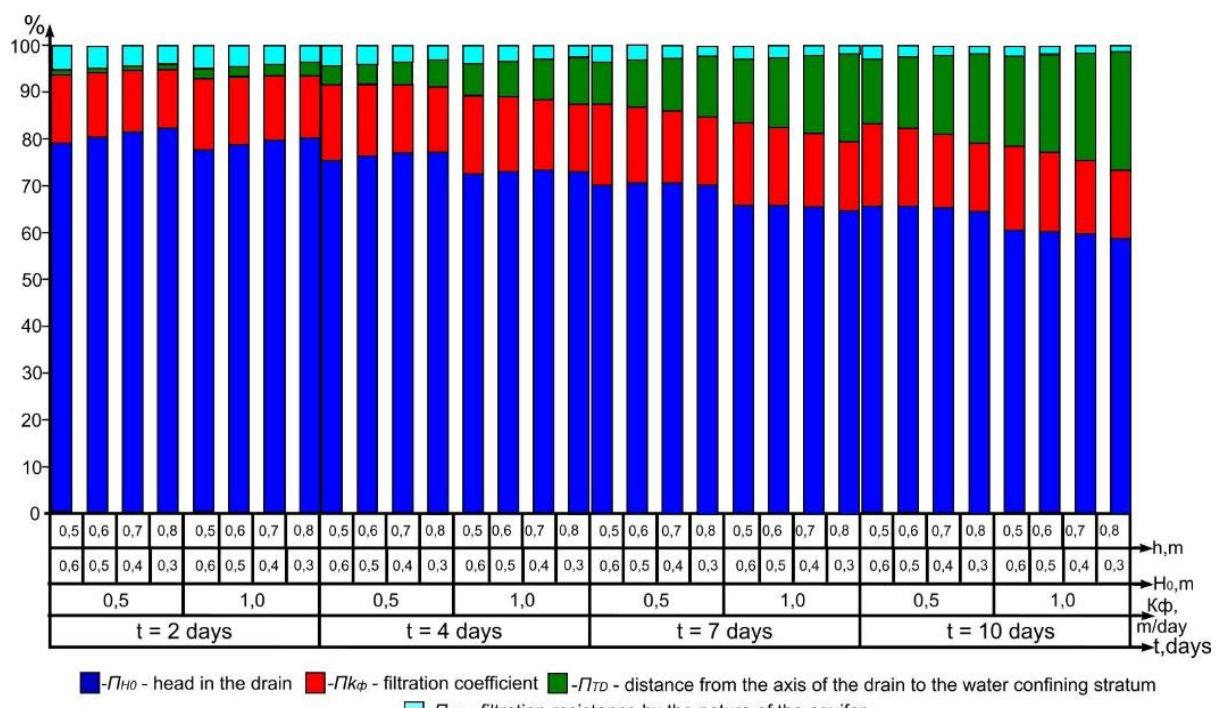

$\square-\Pi \Phi_{0}$ - filtration resistance by the nature of the aquifer

Fig. 3. Histogram of the influence of the main factors on the distance between drains, which operate with subsoil moistening

Thus, the water supply module has a significant effect on the value of the interdrain distance as the main design parameter of the CIS elements, it is $73 \% \ldots 94 \%$, and determines the efficiency of its operation in the mode of subsurface irrigation. 
Since the water supply module has a pronounced probabilistic nature of formation, it becomes necessary to assess the performance (reliability) of the collector-drainage network of the CIS, operating in the mode of subsurface irrigation, and, accordingly, to determine the probabilistic intervals of its value by calculating the confidence intervals of interdrain distances.

In this case, the probability of deviation of the calculated parameters outside the probability intervals can be approximately used as the probability of the risk of normal operation of the elements of the collector-drainage network and the CIS as a whole, which operates in the mode of subsurface irrigation.

The above calculations within the framework of the machine experiment make it possible to perform a probabilistic estimate of the distances between drains $B$ at subsurface irrigation with a given necessary confidence probability $\beta$.

So, for example, at $t=4$ day, $k_{\Phi}=0.5 \mathrm{~m} \cdot$ day $^{-1}, H_{0}=0.3 ; 0.4 ; 0.5 ; 0.6 \mathrm{~m}$ the boundaries of the confidence interval for the distances between drains $B$ at subsurface irrigation, with the confidence probability $\beta=0.90$, are illustrated Fig 4 .

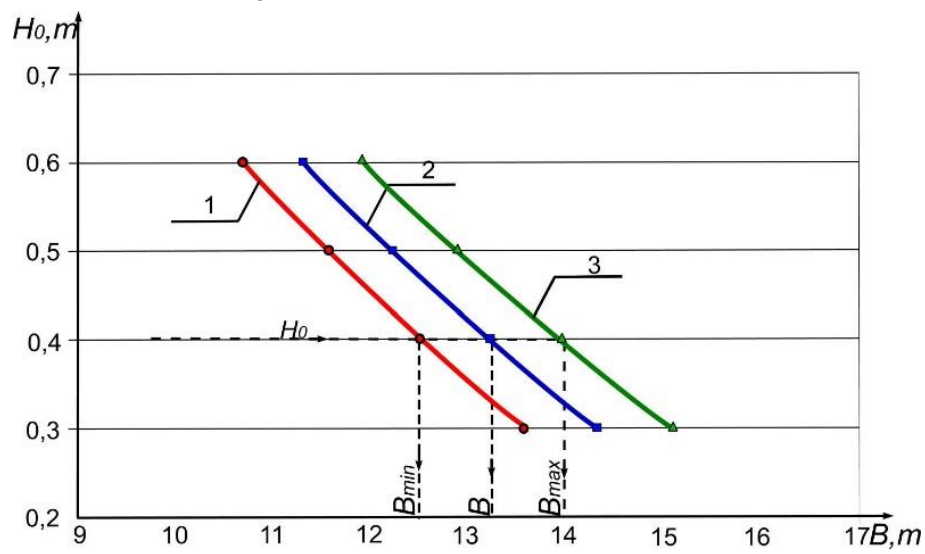

Fig. 4. Graphs $\boldsymbol{B}=\boldsymbol{f}\left(\boldsymbol{H}_{0}\right): 1-B_{\min }=f\left(H_{0}\right) ; 2-B=f\left(H_{0}\right) ; 3-B_{\max }=f\left(H_{0}\right)$

Comparing the average values of interdrain distances $B$ at subsurface irrigation, calculated according to formula (3), with the boundaries of the confidence intervals $B_{\min }$ and $B_{\max }$ corresponding to the confidence probability $\beta=0.90$, it is seen that with the heads in the drains $H_{0}=0.3 ; 0.4 ; 0.5 ; 0.6 \mathrm{~m}$ $-B_{\min }$ in $1.05 \ldots 1.06$ times less than $B_{\max }$ in $1.05 \ldots 1.06$ times more than the corresponding $B$ value calculated at the average values of the parameters by the formula (8).

A similar comparison with a confidence level of $\beta=0.99$ shows that $B_{\min }$ in $1.09 \ldots 1.11$ times less, and $B_{\max }$ in 1.08...1.10 times more than average $B$ values.

Therefore, on the basis of the proposed probabilistic method for estimating the inter-drainage distances for the CIS with subsurface irrigation, the distances between drains calculated by formula (3) can be increased by $1.05 \ldots 1.10$ times (the probability of not exceeding is $\mathrm{P}_{\mathrm{U}}=0.90 \ldots 0.99$ ) to achieve the highest possible technical, economic and environmental efficiency of its work.

\section{Conclusions}

1. Based on the obtained analytical and graphical results, it is established that, as with drainage in the drainage mode, with subsurface irrigation the drainage parameters are significantly affected (at the level of $73 \% \ldots 94 \%$ ) by the head above the drains $58 . . .82 \%$, the soil filtration coefficient and the time of raising the groundwater level is $12 \ldots 18 \%$.

2. These same indicators directly or indirectly form the module of water supply during irrigation measures, the value of which quantitatively and qualitatively reflects the efficiency of irrigation of the drained soils according to their profile and the entire drained array within the system, which determines the parameters of the collector-drainage network operating in the mode of subsurface irrigation, which can be increased by $1.05 \ldots 1.10$ times.

3. Therefore, there is a need to further study the issue of the conditions for the formation, determination and substantiation of the calculated parameters of water supply modules, which 
decisively affect the drainage parameters of the CIS, the technological environmental and economic efficiency of the system as a whole during its reconstruction and construction.

\section{References}

[1] Watkiss P. The Cost of Climate Change in Europe. In: Steininger K., König M., Bednar-Friedl B., Kranzl L., Loibl W., Prettenthaler F. (eds) Economic Evaluation of Climate Change Impacts. Springer Climate. Springer, Cham. 2015. DOI: 10.1007/978-3-319-12457-5_2

[2] Frolenkova N., Rokochinskiy A., Volk P., Shatkovskyi A., Prykhodko N., Tykhenko R., Openko I. Cost-effectiveness of investments in drip irrigation projects in Ukraine. International Journal of Green Economics, 2020, Vol.14, No.4, pp. 315-326. DOI: 10.1504/IJGE.2020.112570

[3] Rokochynskyi A., Volk P., Turcheniuk V., Tokar L., Volk L., Mazhayskiy Y., Chernikova O. The drainage module is an important factor in the design of drainage systems reconstruction and construction projects in the polesia region. Engineering for rural development, 2020, pp. 36-47. DOI: 10.22616/ERDev.2020.19.TF010.

[4] Pasaribu K.N., Lambert L.H., Lambert D.M. et al. Profitability of irrigating for corn, cotton, and soybeans under projected drought scenarios in the Southeastern United States. Irrig Sci, 2021, 39, pp. 315-328._DOI: 10.1007/s00271-020-00707-x

[5] Янголь А.М. Рекомендации по увлажнению осушаемых земель (Recommendations for humidification of drained lands). К.: Урожай, 1965. 88 c. (In Russian)

[6] Дирсе А.Ю. Основы двустороннего регулирования влажности почв в условиях Литовской ССР: автореферат дис. докт. с.-х. наук. (Fundamentals of bilateral regulation of soil moisture in the conditions of the Lithuanian USR: dissertation) Каунас, 1973. 40 c. (In Russian)

[7] Ивицкий А.И. Основы проектирования и расчетов осушительных и осушительноувлажнительных систем (Basics of design and calculation of drainage and drainagehumidification systems). Мн.: Наука и техника, 1988. 311 с. (In Russian)

[8] Скрипчинская Л.В., Янголь А.М., Гончаров С.М., Коробченко С.М. Сельскохозяйственные гидротехнические мелиорации (Agricultural hydraulic melioration). К.: Вища школа, 1977. 352 c. (In Russian)

[9] Олейник А.Я., Поляков В.Л. Дренаж переувлажненных земель (Drainage of wetlands). К.: Наукова думка, 1987. 280 с. (In Russian)

[10] Nikolskii-Gavrilov I., Pchyolkin V. V., Landeros-Sánchez C., Montero-Aguirre Saul. Calculation of Agricultural Drain Spacing Taking into Account Regularity of Water Exchange in the Vadose Zone. Journal of Agricultural Science. 2017, vol. 9, No. 4, pp. 109-115. DOI: 10.5539/jas.v9n4p109

[11] Поляков В. Л. Расчет неустановившегося действия мелиоративного дренажа с углубленным учетом влияния зоны аэрации и инфильтрации (Calculation of the unsteady action of reclamation drainage with in-depth consideration of the influence of the zone of aeration and infiltration). Гідродинаміка і Акустика. 2018. Том 1(91), № 1. pp. 53-69. (In Russian).

[12] Мажайский Ю.А., Рокочинский А.Н., Волчек А.А., Мешик О.П., Езнах Е. Природообустройство Полесья (Environmental management of Polesie). Ryazan: Meshcher.fVNIIIGiM them. A.N. Kostyakova, 2017, 902 p. (In Russian).

[13] Науменко I.I. Надійність споруд гідромеліоративних систем. К.: ІСДО, 1994. 424 с. (In Ukrainian).

[14] Науменко I.I., Токар Л.О. Розрахунок віддалей між дренами осушувально-зволожувальних систем як функції випадкових величин (Calculation of distances between drains of drainage and humidification systems as a function of random variables). Гідромеліорація та гідротехнічне будівництво. Збірник наукових праць. 2001. Вип. 26. pp. 83-94. (In Ukrainian).

[15] Вентцель Е.С. Теория вероятностей (Probability theory). М.: Наука, 1969. 576 c. (In Russian).

[16] ДБН В. 2.4-1-99 Меліоративні системи та споруди (Melioration systems and structures). К.: Держбуд України, 1999. 112 с. (In Ukrainian). 